\title{
The Place Of Karakalpak Ethnoculture In The Integration Of Society
}

\author{
Halima Kadirova \\ Doctor Of Philosophy (PhD) In Social Sciences, Associate Professor Tashkent State Pedagogical \\ University Named After Nizami Uzbekistan, Tashkent
}

Journal Website:

http://usajournalshub.c

om/index,php/tajssei

Copyright: Original content from this work may be used under the terms of the creative commons attributes 4.0 licence.

\section{ABSTRACT}

This scientific article highlights the place and role of the Karakalpak ethnic culture in the development and preservation of the identity of the people. The authors analyze the culture and life of the modern Karakalpak family, which inherits to the next generation the traditional way of life associated with national holidays and traditions, dastans performed by Karakalpak bakhshi (singers), legends and legends of the past, told by the older generation. The article argues that social changes in the global space contribute to the emergence of certain changes in the content of cultural identity, language, art, spiritual categories, which are elements of the basis of the national identity of each nation and various ethno-regional units, which further strengthens the study of this issue under the influence of the process of globalization.

\section{KEYWORDS}

Karakalpak culture, identity, awareness of national identity, globalization, ethnology, ethnos, ethnocultural, cultural heritage, morality, renewal, socialization, stability, family, generation, ancestors, laws of ethics, smart, institutions, development, history, archeology, ethnography, folklore, art history. 
In the modern globalized world, the study of the traditional culture of peoples, national ethnic issues, being relevant as a phenomenon of social culture in some scientific fields, such as anthropology, ethnology, and sociology, occupy a separate place. The term "globalization "was first used by Ted Levitt in a 1983 article in the Harvard Business Review. In 1942, the famous Russian-American sociologist and cultural critic Pitirim Sorokin wrote in his book "Man and Society in a disaster»: "Disasters are not an exclusive evil: along with their destructive and harmful actions, they also play a constructive and positive role in the history of culture and human creative activity. For humanity, catastrophes are of great educational significance" (Baiburin, Toporkov 1990: 427). In society, the importance of people, firms and markets is increasingly expanding, and the authority of the state is shrinking, says Kenichi Ohmae, a Japanese consultant at Harvard Business School, in his work "The Borderless World". He says: "In this process, all peoples fall under the influence of the global market, and the traditional state loses its naturalness." M. Y. Chmerkovskiy considers globalization as a product of modernization. And on this basis, he comes to the conclusion that globalization is a legitimate consequence of the crisis of the socialist modernization project (PIM 2001: 132).

\section{MATERIALS AND METHODS}

The processes of modern world globalization reflect the socio-cultural changes taking place around, the peculiar approaches to the issues of "identity", "consciousness of national identity"," ethnic " in the social sciences, the characteristics of states appearing on the world map.

Because in the context of globalization, interest in local culture is based on a unified form of ethno-cultural properties of a behavioral nature, which lead to a tangible disappearance of peculiar properties.

Therefore, "local", "regional" and "global" changes necessarily have a positive or negative impact on the future fate of the nation. The positive side of the influence of globalization is that it accelerates the rapprochement of peoples, states, national cultures and economies, the negative side of the influence in the processes of globalization, which are increasing all over the world, is that the culture, language, traditions of thousands of small and backward ethnic groups and nations cannot compete with the national culture, rich language of large nations and are gradually moving away from active socio-economic life. Therefore, due to modern globalization, the destruction of a certain level of continuity between the emerging new values and the life experience of humanity requires a special study of the problems of national identity and self-consciousness, changing in the modern process of various threats.

Social changes in the global space contribute to the emergence of certain changes in the content of cultural identity, language, art, spiritual categories, which are elements of the basis of the national identity of each nation and various ethno-regional units, which further strengthens this issue under the influence of the process of globalization. 
While, as a result of globalization, integration, informatization and scientific and technological progress of society, the intellectual potential of human development, progressing at an accelerated pace, serves to improve the economy of the nation, peoples and nationalities living in different countries, ignoring the process of national identity of peoples (awareness of national identity) increases the risk of losing the national identity of peoples. As a result, it is impossible to fill its place.

As the President of Uzbekistan Sh. Mirziyoyev emphasized: "In recent years, there has been a profound geopolitical transformation of the world and the destruction of the previous systems of security and stability. The process of globalization is accelerating, which leads not only to the growth of human opportunities, but also to the strengthening of contradictions, the deepening of the gap between rich and poor countries. As a result of the totality of all these processes, unprecedented threats to peace and stability have emerged, both in their essence and in their scope of action of a transnational nature" (Mirziyoyev 2017: 31).

\section{RESULTS AND DISCUSSION}

Another reason for considering the national consciousness of peoples as an object of independent research in the context of globalization is related to the formation of national consciousness in countries that have achieved independence, and the growing need for it. The processes of globalization lead to the disappearance of established stereotypes of thinking, moral foundations, national traditions and the emergence of a global consciousness and global culture. This happens simultaneously with the national identification process... Therefore, this process occurs simultaneously with the desire to preserve the ethnic culture, national identity, this is manifested in the person's awareness of himself as part of a certain ethnic society. (Safaev 2005: 271)

Today, the global event is the protection of local national traditions and peculiarities (Sapozhnikova 2013: 60-63). Since the real threat of globalization to modern society shows the desire to point out its negative consequences.

After a comparative analysis of modern traditions and customs and their significance in modern society, Aliev A. K. concluded that " no matter what heights the development of society reaches, it will, as usual, preserve simple stereotypical relations controlled by traditions." (Aliev 2003: 62-63)

On this basis, in places where traditions and customs exist, regardless of what a modern society is, there are traditional social institutions inherent in that society. Because traditions and customs are one of the main structural parts of social institutions (Davletiyarov 2019: 23).

It is necessary to take into account, says the historian M. M. Askarov, that Central Asia has always been a center of mutual influence and mutual displacement of different ethnic groups, tribes, peoples, different religious and confessional beliefs, diverse languages and dialects, diverse cultures and values. Determining the boundaries of identity in such a situation is particularly difficult, and this is only possible through many years of research in this field (Askarov 2019: 62). 
Awareness of national identity and its preservation not only in Uzbekistan, but also in developed countries today is becoming an urgent problem, because national identity is manifested when the past cultural heritage of peoples is preserved. Therefore, today many research centers and research institutes deal with issues of national relations, ethnic identity in the international framework for the study of the ethnic origin of the peoples of different regions in the world of ethnosociology. Because it is within the framework of the activities of these institutions that the issues of socialization of the individual and the process of awareness of national consciousness are studied.

These issues, being the priority directions of the development of social and humanitarian sciences in foreign countries, different aspects of this problem are studied from the point of view of social anthropology, ethnology and ethnosociology. For example, the Institute of Ethnology and Anthropology at the Russian Academy of Sciences dealt with the issues of "Research of ethnic, civil and other forms of social consciousness", the "Center for Interethnic Studies" organized at the Institute of Sociology - "Interaction and coherence of state, civil, ethnic and religious identity in a changing society", the Research Council for Economic and Social Affairs in the city of Cardiff in the UK studied issues of identity in ethnic and religious relations, the Institute of Race Relations in London - Questions of social and legal equality of ethnic groups, the French Institute for Central Asian Studies deals with the culture, lifestyle and ethnic identity of the peoples of Central Asia. (Kadirova 2020: 5)

During the period of increasing integration of the world community, the scientific study of the existence of the culture of various ethnic groups ensures the social development of society. Social institutions are one of the important chains in the composition of ethnic culture, which are of great importance in passing on the rich historical and spiritual culture of humanity as a heritage from generation to generation.

After the independence of Uzbekistan, there was an increased interest in the need for awareness and the phenomenon of the processes of national identity of the peoples of Central Asia, in particular the Uzbeks, Karakalpaks, Kazakhs, Kirghiz and Turkmens. The restoration of cultural heritage was also identified as an important task at the state policy level. Without studying and taking into account the history of traditional culture, State policy is not implemented. Uzbekistan is a unique country where representatives of various nations, ethnic groups and faiths are gathered. The country has all the conditions for preserving the culture, traditions, and customs of the peoples (Mirziyoyev 2018: 367). Uzbekistan is a multinational republic in the world.

A comparative analysis of the data revealed that in 1939 the population list included 97, in 1959 - 113,1979 - more than 120 nations and ethnic groups. In the list of the population of 1989, more than 125 nations and ethnic groups lived in Uzbekistan, the total number of which was 19 million 810 thousand people, as of January 16, 2021, they exceeded 34.5 million. People [gazeta.uz].

In modern times, more than 130 nations and ethnic groups live in Uzbekistan. For a sociophilosophical analysis of the process of awareness of national consciousness, which is 
an integral part of the identity of the Karakalpak people, it is necessary to briefly focus on the historical process that is the basis for its formation as a nation and its development as a people. As shown in written historical sources, the formation of the Karakalpaks as a nation rests on a long historical period. Therefore, the process of their awareness of national consciousness was carried out in an indissoluble connection with the formation of the nation.

Among the peoples of Central Asia, the Karakalpaks, along with their social origin, traditions, customs, language and peculiar cultural wealth, are considered one of the ancient peoples with an ancient culture. It is known from history that the ancient stages of the ethnogenesis of the Karakalpaks are associated with the Saka and Massaget tribes who lived in the Amu Darya Delta and the Aralokaspian desert in the VII-IV centuries BC. In the VII-IV centuries, according to the Christian chronology, the Huns migrated to the shores of the Aral Sea, which later mixed with local tribes. As a result of the partial mixing of the Turkic tribes with the local population in the VI-VIII centuries, the peoples of the Aral coast-the Bizhanaks and Uguzs-were formed. On this basis, in the VIII-X centuries, the process of formation of Karakalpaks began among the Bizhanaks and Uguz. (NSAK 1962: 411-413). Part of the Bizhanaks migrated from the banks of the Irtysh, mixing with the Kipchaks, they gradually mastered and adopted their language. In the manuscripts of historical sources "Black Hoods" (Russian chronicle), information about this is given. The Karakalpaks lived in the middle and lower reaches of the Syr Darya and in the lower reaches of the Amu Darya, and together with the Uzbeks of the Aral Sea created a state (the
Rule of the Aral Sea), the capital of which was first Kungirat, and then Shakhtemir (modern Chimbay district). The Karakalpaks were half nomadic, engaged in animal husbandry, agriculture, and fishing. In 1924, in the process of dividing the regions, taking into account the nationalities, the Karakalpak Autonomy was formed, which became part of the Kazakh Autonomy (NSAK 1962: 411-413). In 1930, on July 20, the Karakalpak Autonomous Region became part of the RSFSR. In 1932, on March 20, it was renamed the Karakalpak ASSR. Since 1936, it became part of the Uzbek SSR. A joyful event in the life of the Karakalpak people was the declaration of the sovereign Karakalpak Republic on December 14, 1990, which was reflected in the Law on the Independence of the State of the Uzbek Republic on August 31, 1991 (UME 2003: 94.).

With the achievement of Uzbekistan's independence, a new period began for the Karakalpak people. The political, economic, spiritual and cultural trends of the Karakalpak people have radically changed. All opportunities were created for studying the national cultural heritage, based on the needs of the people in the study of their culture, religion, spiritual and cultural heritage. Now the Karakalpaks, based on the created opportunities, strive to restore the forgotten values, to realize the national identity, since the existing peculiar spirituality and values of this people are important for studying in modern times.

"The Karakalpaks are a generous, wise and generous people. They are a people whose spirit is imbued with the teachings of such saints as Sultan Uwais Karantii, Hakim ota. Love for this sacred land made great poets of Kunkhoja and Berdakh, called for the struggle 
for freedom of such heroes as Yernazarbiy, Alloyar Dosnazarov" - so says the First President of Uzbekistan Karimov I. (Karimov 2000: 110).

Indeed, the Karakalpak people, as well as multinational peoples, have a rich spiritual and cultural heritage, an ancient historical past, so the study of its undisclosed facets, the use of instructive aspects for the updated modern period is a requirement of time. As scientists recognize, to define a country, a people, there must be such features as: language, region, existence within a certain state, unity of economy, culture, religion, traditions and customs, values, solidarity of an ethnic group. However, during the formation of the Karakalpak people, these characteristics changed in different periods and had a different impact in each of the periods.

After the independence of Uzbekistan, the national, ethnic and civil identity of the Republic of Karakalpakstan was given special attention, so the citizens of Karakalpakstan are considered the second indigenous nationality of the Republic of Uzbekistan.

The national traditions of the Karakalpaks, due to the fact that they lived next to such ancient Turkic peoples of Central Asia as the Uzbeks, Kazakhs and Turkmens, were inextricably linked and similar to their traditions, customs, and national values. As it is known from sources, the formation of the ethnogenesis of the Karakalpak people was inextricably linked with the history of the ethnic groups of the Uzbek people. The study of the cultural heritage of the Karakalpak people as an integral part of the Uzbek people is reflected in the issues of interethnic harmony in the "Strategy of Actions for the Further
Development of the Republic of Uzbekistan" for 2017-2021.

President of Uzbekistan Sh. Mirziyoyev on November 10, 2016 in his speech "I am not only the son of the Uzbek people, but also of the Karakalpak people" during a meeting with representatives of the Karakalpak Republic said: "My close acquaintance with Karakalpakstan, or rather my love for this land, and my lifelong fascination with it began when I was a student. When we were picking cotton in the Jizzakh and Syrdarya regions, after working around the campfire, the boys and girls from Karakalpak read the poems of Kunhuj, Ajiniez, Berdakh, and danced. We were surprised. Then, when I first heard the Karakalpak folk songs "Buzatov", "Aidinlar", "Dembermes", I was fascinated and this feeling has remained with me to this day (Mirziyoyev 2017: 204). Indeed, the mythological, ethnic, artistic and mythological traditions of the Karakalpak nationality, the rich musical culture not only in the Khorezm region, but also in Central Asia and the Middle East influenced the development of this culture. In addition, as a result of studying the history, archeology, ethnography, folklore, art history of the Karakalpak people, rich materials on the history, culture, fiction, religion, national traditional family values are collected, the analysis of which from the historical and philosophical point of view confirms that the Karakalpak national culture is of great importance in the awareness of the national identity of the people, where family relations are important. The territory of the republic currently occupies 166.6 thousand $\mathrm{m} 2$. Compared to other regions of Uzbekistan, the land area of Karakalpakstan is the most extensive. The administrative and regional structure of the Republic consists of 15 
districts: Amu Darya, Beruniy, Karauzak, Kegeyli, Kungrad, Konlikul, Muynak, Nukus, Tashtakupir, Turtkul, Khuzhaili, Chimbay, Shumanay, Buzatov, Ellikkala, the city of Takhyatash and the capital of Nukus. There are 12 cities, 14 urban-type settlements, 124 villages and citizens ' gatherings. The modern Karakalpak people, although considered an indigenous stratum of the population, are a minority. At the beginning of 2014, the population of the Republic was 1 million 736 thousand people. According to 2019 data, the total population of the Karakalpak Republic is 1 million 869,000 people (Kadirova 2020: 87), among which $32.1 \%$ are Karakalpaks, 32.3\% are Uzbeks, 26.3\% are Kazakhs, and other peoples who have lived in this region since ancient times, that is, Turkmens, Koreans, Tatars, Russians, Ukrainians and others, make up 9.3\% (Alimov 2019: 32).

The first information about the Karakalpak tribes is found in the works of Russian scientists, travelers and officials (Ya. Khanykov, P. Rychkov, A. V. Kaulbars, A. L. Kun, P. P. Ivanov, A. S. Morozov, B. A. Andrianov, R. Kosbergenov, T. A. Zhdanko). Special ethnological study of the Karakalpak people began in the first half of the XX century. The history of the origin of the people and their economy is studied in the works of P. P. Ivanov, where valuable information is given (Ivanov 1934: 178-200).

Information about the historical past of the Karakalpaks is also given in the work of T. A. Zhdanko "Essay on the history of ethnography of Karakalpakia". The work presents information about the clan structure and social structure of the Karakalpaks in the XIX-early XX century, analyzes their location, their relationship with other peoples. The poetic works of the classic of Karakalpak literature, Berdakh, also contain information about the Karakalpak roots. So, in the work "Shazhara" ("Genealogy») he described the Karakalpaks in detail. Therefore, this work is considered a valuable source for studying the issues of the ethnic origin of the Karakalpak people, because it contains legends and customs related to the origin of the Karakalpak tribe in verse form. Awareness of national identity, first of all, is associated with the way of life and traditions of past generations of this people. Issues of education are one of the eternal issues of society, which is paid attention to the modern generation to honor and respect traditions, customs, morals, material and spiritual values. An important aspect of the awareness of national consciousness is precisely national and moral education. In this regard, the founder of sociology, O. Comte, wrote that " It is necessary to educate feelings, to develop them through exercises in moral education." (ZES 1996: 222). The process of education and the associated awareness of national identity have always been relevant issues for our people. Because by means of education in the family, individual and social consciousness is formed, which manifests itself in micro and macro processes of awareness of national identity. When we say microcondition, we mean social relations in the family and between close relatives, since the young generation receives the first information about their origin, ethnic history, ancestors, their people, tribe, traditions, and customs in the family. The Karakalpaks have some customs that are not found in other peoples. So, every custom is the national basis of the people. Customs are the path that every nation has historically traveled (Membetov 1995: 15). Especially small ethnic groups ask questions, who are we, how do we differ from others? 
They seek answers by referring to the spiritual and cultural roots, the foundations of national culture (Malichnik 1998: 198).

This situation, on the one hand, shows the growth factor of the national consciousness of the people, on the other, the desire of any ethnic group (regardless of whether it is small or large) to learn the historical roots of the origin of their nationality. The materials collected during the study of the history of peoples are considered the cultural value of the people. Such a culture has a rich material on moral and aesthetic and family education, folk traditions, folk art and handicrafts (Kuznetsova 200: 2). As we emphasized above, the national traditions of the Karakalpaks are similar and interrelated with the traditions and customs of other peoples. For example, the Karakalpaks, like neighboring peoples, treat their elders with respect and a kind of respect. This is especially evident in family relationships during a joint breakfast, lunch or dinner. According to tradition, everyone sits around the tablecloth, taking into account seniority, at the beginning of the table sits the oldest in the family - the father, on his right side-the eldest son and the other sons, on the left side sit the women according to seniority. The meal begins only after the older members of the family. For guests, usually, specially sewn and beautiful national kurpachi are laid. It should be emphasized that the older generation, especially the elders, behave sedately, do not talk much, being a model of serious behavior for young people.

As common signs of the behavior of sedate people, one can name restraint of movements, a low voice, the ability to restrain emotions, a direct and open look (Baiburin 1990: 66). As G. P. Snesarev wrote, the rules of behavior of women in the family were controlled by the socalled "kayvoni" (housewives), who played a leading role in the upbringing of girls before their marriage (Snesarev 1960: 138).

Therefore, older women were treated with respect and respect not only in the family, but also in the whole society. It should be noted that the colloquial form in the family also reflects the age, gender, social status and level of kinship. Among the Karakalpaks, it is considered unethical to call relatives by their first names, even to the older generation. They are not only direct relatives, but also other elders are called by the terms of kinship. For example, older people are called "ota", " aka "(in local: ata, aga, azhaga), ana - in the sense of" grandmother " (apa), the grandmother on the father's side - buvi (azhe), the mother of the son - in - law - opa azhapa, kenoyi, kelin (daughter-in-law) - kishe, the wife of the husband's brother-ovsin (sheshe). There is another form of address when communicating. If the father is absent during communication, then they say "kari ota" (garre eke), if the mother is absent, then they use the term "kampir" ("old woman"). Later, the citizens began to introduce the Russian words "mom" and "dad"into the process of local colloquial speech.

Clothing is an expression of the national culture of each nation. According to Suloeva $M$. A., in the traditional culture of any ethnic group, clothing occupies a special place, since it encodes information about the perception of the surrounding world. It is not only a mediative link that connects its owner with other cultures, but also participates in the process of translating their own traditions, behavioral patterns, and is an important factor of self-identification (Suloeva 2020: 45). 
Distinctive men's clothing is "shapan" or "shekpen", a traditional robe made of raft fabric. The shapans were quilted (syrylgan) and not quilted (syrylmagan). For young men, these robes were made of brighter colorful shades, and old men were dressed in white. From the women's clothing of the Karakalpaks, a colorful robe with an embroidered national ornament and a headdress, which is called "saukele" (KGM Foundation 3, MPI department), is clearly distinguished. But, unfortunately, today's young people do not wear national clothes, except for weddings and holidays.

Another important custom in the life of the Karakalpak people is the marriage of girls and the marriage of young men. So the parents of the girl and the boy agree among themselves, the girl's kalym is determined. After the engagement and payment of the kalym, the future groom, according to the customs of the Karakalpaks, has the right to meet and talk with the girl with a special gift. The amount of kalym per girl varies and is different. In addition to the kalym, according to the customs, tribute is given for the mother's milk, tribes and similar customs that must be performed. In due time, the bride is seen off. The girl's parents, based on their social status, build a ut (home) for their daughter. After the send-off, the groom's parents hold a "face opening" ceremony. In addition, various events (weddings) are held at the birth of a child, circumcision, muchal (birthday according to the twelve-year cycle of chronology). The lifestyle of the Karakalpaks, who have lived for many years on the banks of the Aral Sea and the Amu Darya, is peculiar and unique, semi-nomadic and semi-sedentary. This is due to their geographical location, the region of the republic consists of an oasis, steppe and semi-desert. The Karakalpaks were engaged in cattle breeding, leading a sedentary lifestyle engaged in agriculture, fishing and hunting. Because the coast of the Amu Darya, covered with tugai, was rich in wild animals and birds.

In every Karakalpak family, both men and women had their own responsibilities. For example, in livestock families, the duties of men and women require each other to complement each other, the task of men is mainly to drive the animals to pasture, but the woman also helps him. A man in the pasture watches over the herd, a woman, returning home, does household chores: washes, cleans, cooks food. In the evening, she helps her husband drive the herd into the pens, and the women are also engaged in making wool, preparing bedding, clothing, and weaving carpets from it.

In families where they were engaged in fishing, the men caught fish, the women cleaned them, salted them, smoked them, that is, they were the helpers of the men, freed from household chores. In the families of livestock breeders and hunters, women used to process skins, sew special clothes from them, in modern times this work is carried out in special workplaces. The way of life of the people in this difficult period of development is undergoing drastic changes, the place of past ethno-and subcultures is occupied by the concepts of common cultures, the spiritual and social appearance of nationalities and peoples is changing. The preservation of the spiritual and cultural consciousness of the nationality becomes one of the first tasks to be solved. The family, in its true sense, while preserving national traditions and customs, values, must show unanimity with modernity in order to resist the threats and cataclysms of modern times. The family should be the cradle of 
values, preserve the continuation, the health of the generation. Ethnography, national traditions, customs, legends and tales become a fairy tale. Because the glorious past and traditions of the Karakalpaks are connected with the Aral Sea. Such dastans as" Gurugli"," Alpomish"," Kirkiz "and" Aikulesh " reflect the way of life and traditions of the people, all the feats and heroism in them glorify the way of life and traditions of the past. The nomadic way of life is reflected in the art and culture of this people. The concept that a horse is the wings of a horseman appeared in these dastans, songs and legends reflect the sound of the waves of the Aral Sea and the Amu Darya.

Karakalpak women are taught from childhood to sew uts (material for a yurt), to cook food from fish and poultry. Wheat and corn were important in everyday life, they were used to prepare and bake tortillas (churek), bugursaki, chelpak (fried dough), from corn flour mixed with pumpkin, they baked "zagora" bread. The Karakalpaks have another custom that is not found in any other people. For example, if someone comes to the house without an invitation, then the hosts are sure to invite you to the table, ask you to taste at least a piece of bread, if the guest is during lunch or dinner, then he is necessarily put at the dasturkhan and fed. This is already evidence of the hospitality and benevolence of the Karakalpaks. The Karakalpak people have always sought to preserve national traditions and customs, to be in harmony with modernity, research in this regard was based on mutual respect in the family. The Turkic peoples have a custom: in the father's house, daughters are considered a guest, they are taught to do this from childhood, they are respected and dear. In the husband's house, they are considered housewives. However, the young daughter-in- law can not sit at the same table with relatives until she gives birth. The birth of a child is a sign of belonging to the husband's family. Karakalpaks, like Kazakhs, cannot marry a relative, brave young men steal girls from another tribe, and thus this custom is considered an important factor in preserving the national gene pool. This tradition is an ageold custom inherent in a nation with a nomadic lifestyle.

In the family, there are the initial and main stages of education, the initial stage is carried out directly in the family, where sons and daughters are prepared physically, based on the possibilities and lifestyle, and are prepared for the main stage. The main stage prepares young men to become men who can benefit the people and the nation, teach them socialization, behavior in society. The main criterion of education is national traditions, customs and values. Karakalpak young men, along with the ability to care for cattle and be riders, to master all aspects of the way of life of the nomadic people, should be able to sing dastans, which contributes to the feeling of the meaning of these dastans (poems).

Since ancient times, the Karakalpaks have inherited customs that provide for the preservation of reservoirs in cleanliness, careful attitude to the surrounding natural world. According to the relics of ancient beliefs, water and fishing equipment: kayik (boat), au (net) had sacred properties. For example, in order to get pregnant, childless women traveled by boat across the Amu Darya and arranged sadaka- a sacrifice to God. For the same purpose, childless women walked around the mast of the boat of an experienced fisherman three times and touched it. Saint 
Nuh (biblical Noah) was considered the patron saint of the boat (Esbergenova 2020: 126).

Raising a child in respect based on the historical past is considered an immortal tradition of the Karakalpak people. Young men sing dastans, girls-songs, dastans and songs are examples of oral folk art, thus creating eternity. In the Karakalpak ulans (songs), the winds blow in the wide steppes, the waves of the Amu Darya and the Aral Sea splash, through the singing of the singer, the listener also has a spirit of courage. Traditions of the past are transmitted to generations through signs and customs, definitions of lifestyle, culture, customs are transmitted through works of art, on the basis of comparison, it is necessary to ensure the survivability of the heritage of the past, every representative of the nation should be devoted to the traditions of the past. It should be noted that folk music is considered an important dialectical medium for its cheerfulness and calmness. The nation, while preserving its past, must bring it to future generations. In the modern Karakalpak family, legends and legends passed down by the older generation, dastans performed by bakhshi (singers), national holidays and traditions, lifestyle-all this is passed down to generations. In the Republic, special attention is paid to the promotion of art and culture in each region, in particular, musical culture, traditions and customs, artistic traditions, and the introduction of the secrets of the national art "makom"into the minds of young people. In particular, in the Decree of the President of the Republic of Uzbekistan. No. PP-3990 of 01.11. 2018 "On the holding of the international festival of Bakhshi art" defines the current tasks of " preserving and developing a wide public awareness of the unique examples of the Uzbek national art of the Bakhshi storytellers, increasing young people's respect and interest in this art form, strengthening friendship and brotherhood of peoples, expanding the range of creative ties, cultural and humanitarian cooperation on an international scale." Folk songs are considered not only the spiritual and musical value of the nation, their content reflects national traditions and customs, national mentality. Therefore, songs are not only the aesthetic world of the people, but also a kind of means of education. Because the basis of human feelings are spiritual and moral concepts. Folk songs form the best human qualities: honesty, patriotism, courage, love of work, trust in people, loyalty to friends, self-confidence and responsibility. In addition, to restore people's spirituality, to live in their native land without infringement, of course, historical memory is necessary, since it is a bridge connecting the past and the future with each other.

\section{CONCLUSION}

Regardless of who we are, if every citizen is well aware of the history of their past, the rich spiritual and cultural heritage of their ancestors, then such citizens will be difficult to lead astray, to be influenced by various trends. Deep and comprehensive study and awareness of historical cultural processes, the great spiritual and cultural heritage left by the ancestors, contribute to the fact that both in the life of the country and in the social way of life of people will manifest sharp positive turns. Because through the study of the history of the motherland, our thinking expands, our worldview changes, and most importantly, peace and stability will be strengthened in the country. 


\section{REFERENCES}

1. Aliyev A.K. North Caucasus: modern problems of ethnopolitical development. Makhachkala, 2003.- P.- 62-63 Alimov O. World, politics, society. Revised and supplemented 9th edition. // Guliston., 2019., P-32

2. Askarov M.M. Analysis of identity categories in the late 20th and early 21st century in present-day Uzbekistan (based on English-language materials) / Scientific result. Social and humanitarian research. T. 5, No. 4, 2019. S. 62-77. Baiburin A., Toporkov A. At the origins of etiquette. Leningrad, 1990. - P -66.

3. Davolyalyarov M.M. Traditional social institutions of karakalpaks. Nukus: "Ilim." 2019. - P-23.

4. Esbergenova S.H. Beliefs and rites of caracalpaks associated with fishing. Herald of Anthropology, 2020. № 2(50)

5. Ivanov P.P. Essays of the history of karakalpaks / Materials on the history of caracalpaks. Compilation. M., L.: Academy of Sciences Publishing House, 1935. - P. 991; Ivanov P.P. Materials to study the history of caracalpaks / Karakalpakia. Works of the first conference on the study of the productive forces of the Karakalpak ACSR. Volume II- L.: Academy of Sciences Publishing House, 1934. - P.- 178-200

6. Kadirova X.B. Features of the national identity of the Karakalpak people. Doctor of Philosophy (PhD) dissertation in sociology. - Tashkent: National University of Uzbekistan, 2020.-P-87.

7. Kadirova X.B. Features of the national identity of the Karakalpak people. Abstract of the dissertation for the degree of Doctor of Philosophy (PhD) in Sociology. -T .: UzNU, 2020. P-5
8. Karimov I.A. I consider myself the son of not only the Uzbek, but also the Karakalpak people!/ Our ultimate goal is to independent and prosperity of the Motherland, freedom and well-being of the people.- T-8: Uzbekiston, 2000. P -110.

9. Kuznetsova T.V. Tradition of the people in the culture of post-Soviet Russia. -M.: Moscow State University Herald, Series 7, Philosophy. 2001. №2.

10. Malichnik I.V. The national culture and national consciousness. M.: 1998. P. 5

11. Membetov K. Ethnographic history of the Karakalpaks. Nokis. Karakalpakstan. 1995. -P.-15

12. Mirziyoev Sh.M. We will build our great future together with our brave and noble people. People close to my heart, my soul. Speech at a meeting with voters of the Republic of Karakalpakstan November 10, 2016. Shumonoy. 2017.-P.-204.

13. Mirziyoyev Sh.M. People's Approval is the highest assessment of our activities. T.: Uzbekistan. 2018. P -367.

14. Mirziyoyev Sh. Confidently will continue the path of national development at a new stage.-T: "Uzbekiston" . 2017.- P.-33

15. Sapozhnikova I.A. Phenomenon of modern globalization / Sixth Lazarev readings: the face of traditional culture at the beginning of the 21st century. Chelyabinsk, February 26-27, 2013 Chelyabinsk, 2013. -P.- 60-63

16. Safayev S. Global Processes and National Identity / History and Self-Awareness: Uzbekistan and Germany in the 2oth Century. - T., 2005.- P. -271

17. Snesarev G.P. Materials about primitivecommunal remnants in the customs and rites of the Uzbeks Khorezma / MHE, v. 4. M., 1960. -P.- 138. 
18. Sorokin Pitirim. Man. Civilization. Society. M., 1992. P. 427

19. Suloeva M.A. the role and functioning of traditional women's clothing arresh italy in the modern sociocultural space. Herald of Anthropology, 2020. No 4 (52) P.45.

20. gazeta.uz. The permanent population of Uzbekistan as of January 1, 2021 reached 34 million 558 thousand 913 people, according to the website of the State Statistics Committee. The increase over the past year was 653.7 thousand people, or $1.9 \%$.

21. https://www.gazeta.uz/ru/2021/01/16/pop ulation/ 